\title{
GAMBARAN PERILAKU PENCEGAHAN PENULARAN CORONAVIRUS DISEASE (COVID-19) DENGAN PENDEKATAN HEALTH BELIEF MODEL PADA MAHASISWA FAKULTAS KEDOKTERAN UNIVERSITAS MALIKUSSALEH ANGKATAN 2017
}

\author{
Juwita Sahputri ${ }^{1}$, Rizka Sofia ${ }^{1}$ \\ 1) Program Studi Kedokteran, Fakultas Kedokteran, Universitas Malikussaleh \\ Jl. H. Meunasah Uteunkot, Cunda, Lhokseumawe, \\ Corresponding Author: juwita.sahputri@unimal.ac.id
}

\begin{abstract}
Abstrak
Covid-19 saat ini merupakan masalah kesehatan diseluruh belahan dunia dengan jumlah kasus terkonfirmasi positif dan jumlah kematian yang terus meningkat. WHO telah metapkan Covid-19 sebagai kejadian pandemi. Tingginya kasus Covid-19 ini berhubungan dengan persepsi individu terhadap suatu penyakit yang akan membentuk perilaku pencegahan penularan Covid-19 sesuai dengan peraturan pemerintah. Penelitian ini bertujuan untuk mengetahui perilaku pencegahan penularan terhadap Covid-19 pada Mahasiswa Program Studi Kedokteran FK Unimal angkatan 2017 berdasarkan Health Belief Model. Penelitian ini merupakan penelitian deskriptif, menggunakan metode cross sectional dengan total sampling sebanyak 86 responden. Hasil penelitian didapatkan $65,1 \%$ responden memiliki perilaku pencegahan Covid-19 pada kategori cukup baik. persepsi kerentanan (perceived susceptible) dengan kategori baik sebanyak 28 responden (32,6\%) dan kategori cukup baik sebanyak 58 responden (67,4\%). Persepsi keparahan (perceived severity) kategori baik sebanyak 35 responden $(40,7 \%)$ dan cukup baik 51 responden (59,3\%). Persepsi hambatan (perceived barriers) kategori baik sebanyak 17 responden (19,8\%) dan cukup baik 69 responden (80,2\%). persepsi manfaat (perceived benefits) didapatkan kategori baik sebanyak 45 responden (52,3\%), cukup baik 39 responden (45,3\%) dan kurang baik 2 responden $(2,3 \%)$. Pada persepsi isyarat untuk bertindak (cue to action) didapatkan kategori baik sebanyak 47 responden $(54,7 \%)$ dan cukup baik 39 responden (45,3\%). Kesimpulannya persepsi HBM dan perilaku pencegahan Covid-19 responden pada kategori cukup baik.
\end{abstract}

Kata kunci: Covid-19, Health Belief Model, Perilaku pencegahan

Description Oftransmission Prevention Behavior Coronavirus Disease (Covid19)Withapproach Health Belief Model In Students Of The Faculty Of Medicine University Of Malikussaleh Class 2017

\begin{abstract}
Covid-19 is currently a health problem in all parts of the world with the number of positive confirmed cases and the number of deaths continuing to increase. WHO has declared Covid-19 a
\end{abstract}


pandemic. The high number of Covid-19 cases is related to individual perceptions of a disease that will shape the behavior of preventing Covid-19 transmission in accordance with government regulations. This study aims to determine the behavior of preventing transmission of Covid-19 in Medical Study Program Students of FK Unimal class of 2017 based on the Health Belief Model. This research is a descriptive study, usingmethod cross sectional with a total sampling of 86 respondents. The results showed that $65.1 \%$ of respondents had Covid-19 prevention behavior in the fairly good category. perception of susceptibility (perceived susceptible) with a good category as many as 28 respondents (32.6\%) and good enough category as many as 58 respondents $(67.4 \%)$. Perception of severity(perceivedseverity) good category as many as 35 respondents $(40.7 \%)$ and good enough 51 respondents (59.3\%). Perception barriers (perceived barriers) good category as many as 17 respondents (19.8\%) and quite good 69 respondents $(80.2 \%)$. perceived benefits(perceivedbenefits)obtained good category were 45 respondents (52.3\%), good enough 39 respondents $(45.3 \%)$ and unfavorable 2 respondents $(2.3 \%)$. In the perception ofcue to action, there are 47 respondents (54.7\%) good category and 39 respondents (45.3\%) quite good. In conclusion, the respondents' perceptions of HBM and Covid-19 prevention behavior are in a fairly good category.

Keywords: Covid-19, Health Belief Model, Preventive behavior

\section{PENDAHULUAN}

Akhir bulan Desember tahun 2019, dunia dikejutkan dengan adanya penemuan kasus pneumonia yang misterius. Kasus tersebut pertama sekali dilaporkan di Wuhan provinsi Hubei.

Penularan kasus tersebut dikaitkan dengan pasar ikan di Wuhan (1). Kasus konfirmasi positif dan kematian terus meningkat hingga saat ini dan telah menyebar ke berbagai belahan dunia. World Health Organization (WHO) mengumumkan penyakit tersebut sebagai "Coronavirus disease" (Covid-19) yang disebabkan oleh Severe Acute Respiratory Syndrome Coronavirus 2 (SARS-CoV-2) dan menyatakan kejadian tersebut sebagai pandemic (2).

Coronavirus $(\mathrm{CoV})$ menimbulkan penyakit mulai dari manifestasi ringan hingga berat dan bahkan menimbulkan kematian. Manifestasi klinis ringan umumnya berupa demam, batuk, dan sesak nafas yang timbul 2-14 hari setelah paparan virus. Manifestasi klinis berat yang timbul akan menimbulkan pneumonia berat, sindrom respirasi kronis, gagal ginjal, hingga kematian (3).

Penyebaran SARS-CoV-2 dari manusia ke manusia menjadi sumber transmisi utama sehingga penyebaran menjadi lebih agresif. Transmisi SARS-CoV-2 terjadi melalui droplet yang keluar saat seseorang batuk atau bersin. Resiko infeksi akan meningkat terhadap orang yang berhubungan dekat dengan orang yang terkonfirmasi positif Covid-19. Hingga saat ini belum ditemukan pengobatan khusus untuk Covid-19 karena itu masyarakat diharapkan dapat 
menerapkan protokol kesehatan sebagai kebiasaan dalam kehidupan sehari-hari seperti mencuci tangan secara teratur, menggunakan masker, menerapkan etika batuk dan bersin, menjaga jarak minimal 2 meter dengan orang lain, membatasi kontak dengan orang lain, dan menerapkan pola hidup bersih dan sehat untuk mengurangi angka penyebaran virus tersebut (3). Setiap orang adalah faktor terpenting untuk meningkatkan kesehatan. Perilaku benar atau salah dipengaruhi oleh keyakinan, nilai, kecenderungan, dan kebiasaan individu (4).

Perilaku menjadi salah satu faktor penting untuk meningkatkan derajat kesehatan. Sehat atau tidak sehatnya lingkungan kesehatan individu, keluarga dan masyarakat sangat tergantung pada perilaku manusia itu sendiri. Perilaku kesehatan di masa pandemi sangat berhubungan dengan respon seseorang dalam menghadapi pandemi. Setiap orang memiliki penilaian kepercayaan pada tingkat kerentanan dan keparahan masing-masing sehingga melakukan upaya pencegahan terhadap suatu penyakit. Penilaian tindakan sehat untuk pencegahan penyakit dapat dilakukan menggunakan Health Belief Model (HBM) yang meliputi persepsi kerentanan (perceived susceptibility), persepsi keparahan (perceived severity), persepsi hambatan (perceived barriers), persepsi manfaat (perceived benefits), dan Isyarat untuk bertindak (cue to action) $(5,6,7)$

\section{METODE PENELITIAN}

Penelitian deskriptif dengan desain cross sectional, dilakukan terhadap mahasiswa angkatan 2017 Program Studi Kedokteran Fakultas Kedokteran Universitas Malikussaleh. Teknik pengambilan sampel menggunakan teknik total sampling terhadap 86 sampel yang memenuhi kriteria inklusi dan eksklusi.

Instrumen penelitian berupa kuesioner dengan konsep Health Belief Model melalui googleform. Pengukuran instrumen menggunakan skala likert (nilai 1-4) dengan kategori baik: 76\%-100\%, Cukup Baik: 75\%-56\% dan Kurang Baik: $<56 \%$. Variabel yang dinilai adalah : perilaku pencegahan penularan Covid-19, persepsi kerentanan (perceived susceptibility) persepsi keparahan (perceived severity), persepsi hambatan (perceived barriers), persepsi manfaat (perceived benefits) dan persepsi isyarat melakukan tindakan (cues to action). Data yang terkumpul disajikan dalam bentuk univariat (tabel distribusi frekuensi).

\section{HASIL}


Tabel 1 Distribusi Frekuensi Persepsi Pencegahan Covid-19 Berdasarkan HBM

\begin{tabular}{|l|c|c|}
\hline \multicolumn{1}{|c|}{ Kategori Health Belief Model } & \multirow{2}{*}{ Frekuensi } & \multirow{2}{*}{ Persentase (\%) } \\
\cline { 1 - 2 } A. Persepsi Kerentanan (Perceived Susceptible) & 28 & 32,6 \\
\hline Baik & 58 & 67,4 \\
\hline Cukup baik & 0 & 0 \\
\hline Kurang baik & 35 & 40,7 \\
\hline B. Persepsi Keparahan (Perceived Severity) & 51 & 59,3 \\
\hline Baik & 0 & 0 \\
\hline Cukup baik & & 17 \\
\hline Kurang baik & 17 & 80,8 \\
\hline C. Persepsi Hambatan (Perceived Barriers) & 69 & 0 \\
\hline Baik & & \\
\hline Cukup Baik & 45 & 52,3 \\
\hline Kurang Baik & 39 & 45,3 \\
\hline D. Persepsi Manfaat (Perceived Benefits) & 2 & 2,3 \\
\hline Baik & & \\
\hline Cukup Baik & 47 & 54,7 \\
\hline Kurang Baik & 39 & 45,3 \\
\hline E. Isyarat untuk Bertindak (Cue to Action) & 0 & \\
\hline Baik & & \\
\hline Cukup Baik & & \\
\hline Kurang Baik & & \\
\hline
\end{tabular}

Sumber: Data Primer, 2020

Berdasarkan data dari tabel 4.1 berdasarkan Health Belief Model didapatkan persepsi kerentanan (perceived susceptible) dengan kategori baik sebanyak 28 responden $(32,6 \%)$ dan kategori cukup baik sebanyak 58 responden $(67,4 \%)$. Persepsi keparahan (perceived severity) kategori baik sebanyak 35 responden (40,7\%) dan cukup baik 51 responden (59,3\%). Persepsi hambatan (perceived barriers) kategori baik sebanyak 17 responden $(19,8 \%)$ dan cukup baik 69 responden (80,2\%). persepsi manfaat (perceived benefits) didapatkan kategori baik sebanyak 45 responden (52,3\%), cukup baik 39 responden (45,3\%) dan kurang baik 2 responden $(2,3 \%)$. Pada persepsi isyarat untuk bertindak (cue to action) didapatkan kategori baik sebanyak 47 responden $(54,7 \%)$ dan cukup baik 39 responden $(45,3 \%)$.

Tabel 2 Distribusi Frekuensi Perilaku Pencegahan Covid-19

\begin{tabular}{|c|c|c|}
\hline Kategori & Frekuensi & Persentase (\%) \\
\hline Baik & 29 & 33,7 \\
\cline { 2 - 3 } Cukup baik & 56 & 65,1 \\
\cline { 2 - 3 } Kurang baik & 1 & 1,2 \\
\hline
\end{tabular}

Sumber: Data Primer, 2020 
Berdasarkan tabel 4.2 didapatkan distribusi frekuensi perilaku pencegahan Covid-19 yaitu terdapat 29 responden $(33,7 \%)$ pada kategori baik, 56 responden $(65,1 \%)$ kategori cukup baik, dan 1 responden $(1,2 \%)$ pada kategori kurang baik.

\section{PEMBAHASAN}

Hasil penelitian didapatkan responden memiliki persepsi kerentanan (perceived susceptible) yang cukup baik. Persepsi kerentanan merupakan keyakinan seseorang mengenai kondisi kesehatannya atau kemungkinan terkena suatu penyakit yang akan mendorong individu untuk melakukan perilaku pencegahan penyakit tersebut. Seseorang yang merasa memiliki resiko rendah untuk terinfeksi suatu pemyakit cenderung kurang memperhatikan protokol kesehatan, sedangkan apabila seseorang merasa memiliki resiko tinggi untuk terinfeksi suatu penyakit maka akan lebih terlibat untuk melakukan protokol kesehtan untuk mengurangi resiko terinfeksi atau terpapar penyakit (8).

Aspek persepsi keparahan (perceived severity) responden didapatkan pada kategori cukup baik. Persepsi keparahan merupakan Keyakinan yang dimiliki oleh individu yang berhubungan dengan perasaan keparahan suatu penyakit yang dapat mempengaruhi keadaan kesehatannya sekarang dan seberapa besar konsekuensi penyakit tersebut dalam kehidupannya (8). Persepsi keparahan sangat penting untuk mendorong seseorang melakukan tindakan pencegahan. Hasil ini sejalan dengan oleh penelitian Qian dkk di China yang menunjukkan bahwa tingkat kerentanan dan keparahan penyakit sebagai prediktor penting dalam meningkatkan perilaku pencegahan penyakit Covid-19 di China $(9,4)$.

Persepsi hambatan(perceived barriers) merupakan suatu persepsi ada tidaknya hambatan yang dapat mempengaruhi perilaku seseorang dalam menjalankan protokol kesehatan. Adanya hambatan yang berlebihan dalam menjalankan protokol kesehatan akan mencegah seseorang untuk melakukan perilaku kesehatan yang diinginkan. Pada penelitian ini responden masih merasakan hambatan dalam menjalankan protokol kesehatan karena masih perlu beradaptasi untuk menjalankan protokol kesehatan dalam kehidupan sehari-hari (4).

Persepsi manfaat (perceived benefits) pada penelitian ini didapatkan pada kategori baik. Hal ini menunjukkan seseorang merasakan manfaat saat menjalankan protokol kesehatan demi untuk mencegah terinfeksi covid-19. Meningkatkan persepsi mengenai manfaat perilaku 
pencegahan penyakit akan lebih memotivasi seseorang untuk melakukan protokol kesehatan $(10,11)$.

Persepsi isyarat untuk bertindak (cue to action) pada penelitian ini didapatkan pada kategori baik. Merupakan suatu isyarat/ peringatan adanya ancaman masalah kesehatan bagi individu sehingga mendorong individu untuk bertindak. Hal ini dipengaruhi oleh faktor eksternal maupun internal seperti informasi dari media masa, nasehat orang lain artikel koran atau penyakit dari kerabat dll. informasi mengenai manfaat yang didapat dengan menerapkan perilaku hidup sehat dapat menjadi pencetus seseorang untuk memutuskan untuk melakukan timdakan pencegahan suatu penyakit. Apabila seseorang memiliki isyarat pendorong untuk bertindak yang baik maka besar kemungkinan akan melakukan tindakan pencegahan $(10,12)$.

\subsection{Perilaku Pencegahan Terhadap Covid-19}

Dari hasil penelitian dapat dilihat bahwa sebagian besar mahasiswa memiliki perilaku yang cukup baik dalam mencegah penularan Covid-19 dengan menerapkan protokol kesehatan sesuai dengan anjuran pemerintah (4).

Menerapkan perilaku sehat dalam pencegahan Covid-19, merupakan tindakan yang palik baik untuk mencegah penularan atau penyebaran suatu penyakit. Namun, penerapan perilaku kesehatan dalam aktivitas sehari-hari tidaklah selalu mudah untuk dilakukan, karena kurangnya kesadaran berperilaku hidup sehat dan setiap orang butuh untuk beradaptasi dengan kebiasaan baru tersebut. Perilaku kesehatan sangatlah penting guna membantu untuk mengenali serta mengatasi permasalahan Covid-19 yang menjadi pandemi di masa kini. Perilaku tersebut haruslah didasarkan atas kesadaran masing-masing individu, dikarenakan banyak individu yang sebenarnya telah mengetahui berbagai pengetahuan terkait protokol kesehatan ataupun pandemi Covid-19 namun tidak dapat melaksanakannya secara baik di dalam kehidupannya sehari-hari (13).

Hingga saat ini makin tinggi kasus yang terkonfirmasi positif Covid-19 sehingga perilaku hidup sehat menjadi upaya pencegahan yang penting. Penerapan perilaku Hidup Bersih dan Sehat harus diterapkan dalam setiap sisi kehidupan manusia kapan saja dan dimana saja termasuk di dalam lingkungan kampus dan tempat tinggal karena perilaku merupakan sikap dan tindakan yang akan membentuk kebiasaan sehingga melekat dalam diri seseorang (14). 


\section{Kesimpulan}

Adapun Kesimpulan yang didapatkan pada penelitian ini adalah sebagai berikut :

1. Gambaran persepsi responden berdasarkan Health Belief Model pada penelitian ini pada kategori cukup baik

2. Perilaku pencegahan penularan Covid-19 pada responden penelitian pada kategori baik

\section{Saran}

1. Perlunya ditingkatkan kembali program promosi kesehatan mengenai penerapan protokol kesehatan untuk mencegah penularan Covid-19 baik melalui media cetak dan elektronik.

2. Perlunya dukungan berbagai pihak untuk mewujudkan protokol kesehatan dalam kehidupan sehari-hari untuk memutuskan rantai penularan Covid-19

\section{Daftar Pustaka}

1. Routhan, H. A., \& Byrareddy, S. N. (2020). The Epidemiology and Pathogenesis of Coronavirus Disease (COVID-19) Outbreak. Journal Autoimun .

2. Susilo, A., Rumende, C. M., Pitoyo, C. W., Santoso, W. D., Yulianti, M.,Herikurniawan, et al. (2020). Coronavirus Disease 2019: Tinjauan Literatur Terkini. Jurnal Penyakit Dalam Indonesia , 7 (1).

3. Kemenkes RI. (2020). Strategi Komunikasi Perubahan Perilaku dalam PencegahanCovid-19. Jakarta: Kementerian Kesehatan RI.

4. Shahnazi, H., Livani, M. A., Pahlayanzadeh, B., Rajabi, A., Hamrah, M. S., \& Charkazi, A. (2020). Assessing Preventive health Behaviors from Covid-19 Based on the Health Belief Model (HBM) among People in Golestan Province: A Cross Sectional Study in Northern Iran. Research Square , 1-19.

5. Adliyani, Z. O. (2015). Pengaruh Perilaku Individu terhadap Hidup Sehat . Majority : MEDICAL JOURNAL OF LAMPUNG UNIVERSITY , 109-114.

6. Rosenstock, I. (1974). Historical Orgins Of The Health Believe Preventive Health Behavior. Dalam B. M, The Health Believe Model and Personal Health Behavior. New Jersey: Charles B. Slack, INC.

7. Notoatmodjo, S. (2010). Ilmu Perilaku Kesehatan. Jakarta: Rineka Cipta.

8. Glanz, K., Rimer, B., \& Viswanath, K. (2008). Theory, Research and Practice in Health Behavior and Health Education. Orelans: Jossey- Bass.

9. Qian, M., Wu, Q., Wu, P., Hou, Z., Liang, Y., Cowling, B. J., et al. (2020). Phycological Responses, Behavioral Changes and Public Perceptions During the Early Phase of The Covid-19Outbreak in China: a Population Based Cross-Sectional Survey. medRxiv , 1-25.

10. Jose, R., Narendran, M., Bindu, A., Beevi, N., L, M., \& Benny, P. V. (2020). Public perception and preparedness for the pandemic COVID 19: A Health Belief Model Approach. Clinical Epidemiology and Global Health , 1-6.

11. Purwodiharjo, O. M., \& Suryani, A. O. (2020). Aplikasi Health Belief Model dalam Penanganan Pandemi Covid-19 di Provinsi DKI Jakarta. e-Journal atmajaya . 
12. Yanti, N. P., Nugraha, I. M., Wisnawa, G. A., Agustina, N. P., \& Diantar, N. P. (2020).Gambaran Pengetahuan Masyarakat Tentang Covid-19 dan Perilaku Masyarakt di Masa Pandemi Covid-19. Jurnal Keperawatan Jiwa , 8 (3), 485-490.

13. Sakinah, Z. V. (2017). Aplikasi Health Belief Model Dalam Menganalisis perilaku Penggunaan Kacamata Pelindung. Jurnal Promkes, 105-116.

14. Kemenkes. (2020). Menteri Kesehatan (KMK) No. HK.01.07/MENKES/413/2020 Tentang Pedoman Pencegahan dan Pengendalian Covid-19. 